\title{
Kenaikan Berat Badan Ibu Hamil Trimester III berhubungan dengan Kejadian BBLR di Puskesmas Paleran Kecamatan Umbulsari Kabupaten Jember
}

\author{
Dyah Ekowati
}

Universitas Islam Jember

Email: dyahekowati0706@yahoo.com

\begin{abstract}
Abstrak
Selama kehamilan, ibu harus mempersiapkan kehamilannya dengan baik. Ibu hamil yang sehat akan melahirkan bayi yang juga sehat. Berdasarkan laporan dari Puskesmas Paleran, kasus kelahiran BBLR masih sangat tinggi yaitu 33, 3\% dari 97,96\% bayi yang lahir hidup. Faktor yang menyebabkan BBLR salah satunya dalah faktor nutrisi dari ibu hamil berhubungan dengan peningkatan berat badan pada ibu hamil trimester tiga. Rancangan penelitian yang dipergunakan dalam penelitian ini adalah analisis observasional kasus kontrol. Sampel dibagi menjadi dua yaitu sampel kasus dan sampel kontrol. Sampel kasus sebanyak 33 responden dan sampel kontrol sejumlah 66 responden. Variabel yang diukur adalah kenaikan berat badan dan kejadian BBLR. Data dianalisis menggunakan tes chi square. Hasil penelitian menunjukkan bahwa 18 ibu hamil $(18,18 \%)$ yang kekurangan gizi melahirkan 33 BBLR (33,3\%). Hasil analisis bivariat dengan nilai signifikan 10,855 dengan standar eror 5\% 1,985 x2 rabel dimana perhitungan x2 > x2 tabel. Hasil analisis menunjukkan hubungan signifikan antara kenaikan berat badan pada trimester tiga dan BBLR. Kebijakan program diharapkan dapat mencegah dan menangani masalah kekurangan gizi pada ibu hamil untuk mencegah kejadian BBLR.
\end{abstract}

Kata Kunci : trimester tiga, status gizi, BBLR

\begin{abstract}
During pregnancy the mother must prepare as well as possible. Healthy mothers will give birth to healthy babies. According to the employment of labor in the health center in 2017 Paleran LBW cases still high at 33.3\% as much as $97.96 \%$ of the infants born alive. Factors causing LBW one of which expectant mothers nutritional factors associated with weight gain third trimester pregnant women. The design of this study used observational case control analytic approach whereby the sample is divided into two, namely the sample case and control samples. Sampling technique for the case by way of total population sampling as many as 33 respondents, and to control the population by random sampling as many as 66 respondents. The variables measured were weight gain third trimester pregnant women and low birth weight. Analysis of the data used is the chi square test. The results showed 18 pregnant women (18.18\%) were malnourished and 33 newborns (33.3\%) had LBW. From the results of the bivariate analysis obtained significant value 10.855 with a standard error of $5 \%$ price gained $1.985 \times 2$ table, which is where the count $x 2>x 2$ tables. The results of the analysis showed no significant association between weight gain third trimester pregnant women with low birth weight. Program is expected to lower the prevalence of malnutrition among pregnant women to prevent $L B W$.
\end{abstract}

Keywords: third trimester, nutritional status, low birth weight

\section{Pendahuluan}

World Health Organization (WHO) memperkirakan bahwa angka prevalensi BBLR di negara maju terbesar antara 3-7\% dan di negara berkembang berkisar antara 13-38\% untuk Indonesia kejadian BBLR adalah sekitar 14-20\%. Dinas Kesehatan Jember menyebutkan jumlah ibu hamil tahun 2017 sebanyak 40.000 jiwa, dan $10 \%$ diantaranya menderita kurang energi kronis (KEK) yang dapat menyebabkan bayi yang lahir dengan berat badan dibawah 2500 gram atau bayi dengan berat badan lahir rendah (BBLR). Menurut data dari Dinas Kesehatan Jember pada tahun 2017 terdapat 2,48\% kasus BBLR dari $100 \%$ jumlah kelahiran. . Puskesmas Paleran merupakan salah satu Puskesmas yang ada di Kecamatan Umbulsari Kabupaten Jember. Menurut catatan persalinan di Puskesmas Paleran tahun 2017 bayi yang dilahirkan BBLR sebanyak 2,57\% dari 97,96\% bayi lahir hidup. Pada kehamilan terjadi perubahan fisik dan mental yang bersifat alami. Para calon ibu harus sehat dan mempunyai gizi cukup (berat badan normal) sebelum hamil dan setelah hamil. Jika ibu tidak mendapat gizi yang cukup selama kehamilannya, maka janin yang dikandungnya akan menderita kekurangan gizi. Jadi meskipun sudah cukup bulan, bayi tersebut akan lahir dengan berat badan dibawah 2500 gram atau bayi dengan berat badan lahir rendah (BBLR) (Francin, 2014). Beberapa faktor lain yang diperkirakan berkontribusi terhadap kejadian BBLR adalah jarak kehamilan/kelahiran, usia ibu hamil, paritas, kadar hemoglobin, status gizi, jarak kehamilan, usia ibu hamil dan faktor ekonomi. Status gizi yang cukup pada saat kehamilan salah satunya dinilai dari kenaikan berat badan 
selama hamil. Dengan status gizi ibu hamil yang baik maka diharapkan dapat melahirkan bayi dengan berat badan yang normal.

\section{Metode Penelitian}

Penelitian ini menggunakan jenis penelitian observasional analitik dengan pendekatan case control. Varabel bebasnya adalah kenaikan berat badan ibu hamil dan variabel terikat adalah kejadian BBLR. Kenaikan berat badan pada ibu hamil pada trimester tiga kehamilan yang dibandingkan dengan kenaikan berat badan sesuai dengan IMT ibu. Jika IMT kategori kurus maka kenaikan BB ibu hamil $11,5-16 \mathrm{~kg}$, atau IMT kategori normal maka kenaikan BB ibu hamil 12,5-13 $\mathrm{kg}$ atau IMT kategori gemuk kenaikan BB ibu hamil 7- 11,6 kg. Perbandingan kenaikan berat badan tersebut dikategorikan menjadi normal dan tidak normal. Sedangkan untuk berat badan bayi yang dilahirkan dikategorikan menjadi BBLR (BB < $2500 \mathrm{gr}$ ) dan BBLN (BB 2500-4000gr). Data terkait kenaikan berat badan ibu hamil dan berat badan bayi yang dilahirkan diambil berdasarkan data yang ada pada catatan persalinan, kohort ibu hamil dan buku KIA (Kesehatan Ibu dan Anak). Populasi pada penelitian ini adalah bayi baru lahir yang lahir di tenaga kesehatan. Adapun populasi pada penelitian ini dibagi menjadi dua yaitu populasi kasus dan populasi kontrol. Untuk populasi kasus disini sebanyak 33 adalah bayi BBLR dengan berat badan <2500 gram dan dengan memakai perbandingan $1: 2$ maka jumlah populasi kontrol adalah 66 bayi yang lahir dengan berat badan normal yaitu 2500- 4000 gram. Analisa data dilakukan secara univariat (untuk menganalisa data satu variable) menggunakan rumus $x / y$ di kali $100 \%$. Berdasarkan hasil prosentase dapat diintrepretasikan dengan menggunakan kriteria kualitatif yaitu $100 \%$ artinya seluruhnya, 76 $99 \%$ artinya hampir seluruhnya, 51-75\% artinya sebagian besar, $50 \%$ artinya setengahnya, $26-49 \%$ artinya hampir setengah, $1-25 \%$ artinya sebagian kecil, $0 \%$ artinya tidak satupun. Analisa data bivariat dihitung dengan menggunakan rumus uji ChiSquare (x2) dan dihitung dengan menggunakan bantuan program komputer SPSS..

\section{Hasil Dan Pembahasan \\ Hasil}

Karakteristik Responden Berdasarkan Umur di Puskesmas Paleran Kecamatan Umbulsari Kabupaten Jember

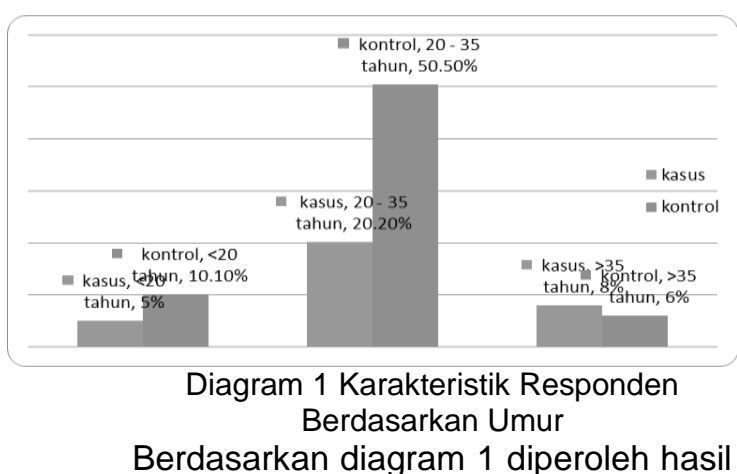

bahwa responden sebagian besar berumur antara 20-35 yaitu sebanyak 50 responden $(50,50 \%)$.

Karakteristik Responden Berdasarkan Pendidikan di Puskesmas Paleran.Kecamatan Umbulsari Kabupaten Jember

Data karakteristik responden berdasarkan pendidikan meliputi pendidikan setingkat SD, setingkat SMP, setingkat SMA dan Perguruan tinggi.

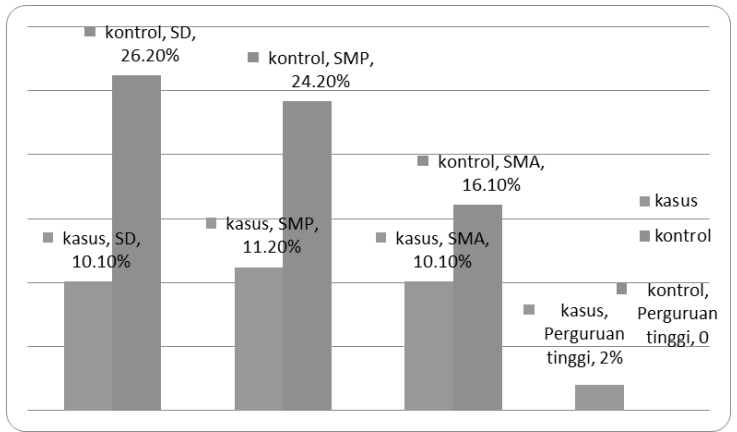

Diagram 2 Karakteristik Responden Berdasarkan Pendidikan

Berdasarkan diagram 2 diperoleh hasil bahwa hampir setengahnya responden lulus pendidikan tingkat sekolah dasar (SD) yaitu sebanyak 26 responden (26,20\%).

Karakteristik Responden Berdasarkan Pekerjaan istri di Puskesmas Paleran Kecamatan Umbulsari Kabupaten Jember

Data karakteristik respondenberdasarkan pekerjaan meliputi ibu rumah tangga, buruh, petani dan wiraswasta.

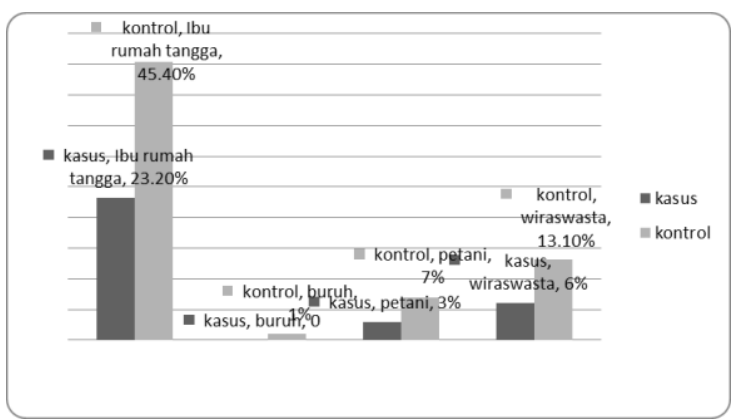

Diagram 3 Data Karakteristik Responden Berdasarkan Pekerjaan istri

Berdasarkan diagram 3 diperoleh hasil bahwa hampir setengahnya responden adalah ibu rumah tangga (IRT) yaitu sebanyak 45 
responden (45,40\%).

Karakteristik Responden Berdasarkan Pekerjaan Suami di Puskesmas Paleran Kecamatan Umbulsari kabupaten Jember.

Data karakteristik responden berdasarkan pekerjaan suami meliputi buruh, petani, wiraswasta dan guru. Adapun frekuensi dari masing-masing pekerjaan

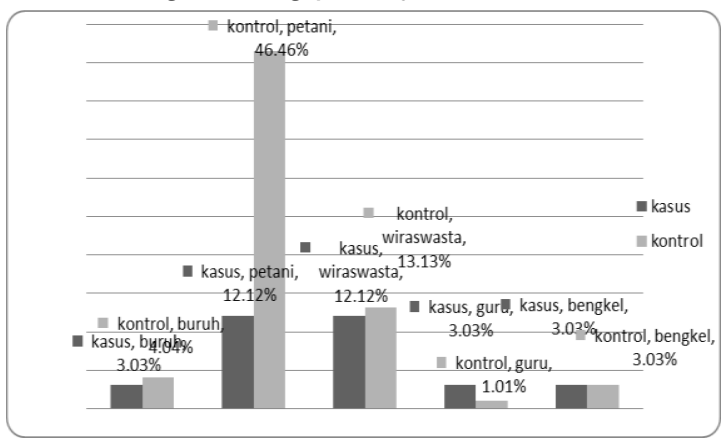

Diagram 4 Data Karakteristik Responden Berdasarkan Pekerjaan Suami

Berdasarkan diagram 4 diperoleh hasil bahwa sebagian besar responden mempunyai suami bekerja sebagai petani yaitu sebanyak 46 responden $(46,46 \%)$.

Karakteristik Responden Berdasarkan Suku di layanan kesehatan Puskesmas Paleran Kecamatan Umbulsari Kabupaten Jember.

Data karakteristik responden berdasarkan suku bangsa meliputi Jawa dan Madura. Adapun karakteristik responden berdasarkan suku bangsa

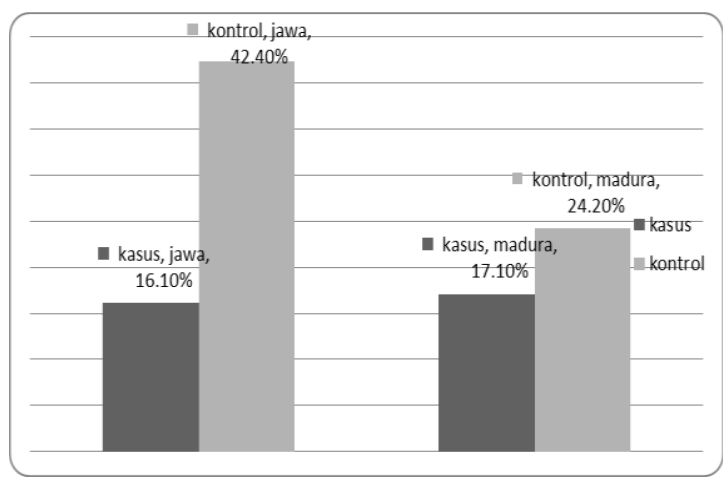

Diagram 5 Data Karakteristik Responden Berdasarkan Suku

Berdasarkan diagram 5 diperoleh hasil bahwa sebagian besar responden bersuku Jawa yaitu sebanyak 42 responden $(42,40 \%)$.

Karakteristik Responden Berdasarkan Frekuensi ANC di layanan kesehatan Puskesmas Paleran Kecamatan Umbulsari Kabupaten Jember

Dari hasil tabulasi data mengenai frekuensi ANC responden

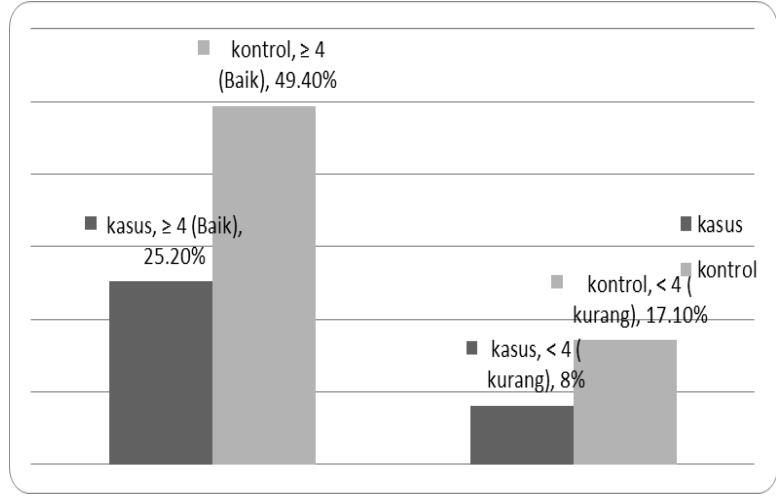

Diagram 6 Distribusi frekuensi responden berdasarkan frekuensi ANC

Berdasarkan diagram 6 diatas, menunjukkan sebagian besar responden memiliki fekuensi ANC $\geq 4$ (dalam kategori baik) yaitu sebanyak 49 responden $(49,40 \%)$. Karakteristik Responden Berdasarkan Kenaikan Berat Badan (BB) lbu Hamil Trimester III di Puskesmas Paleran Kecamatan Umbulsari Kabupaten Jember.

Dari hasil tabulasi data mengenai Kenaikan Berat Badan (BB) Ibu selama Hamil Trimester III pada responden

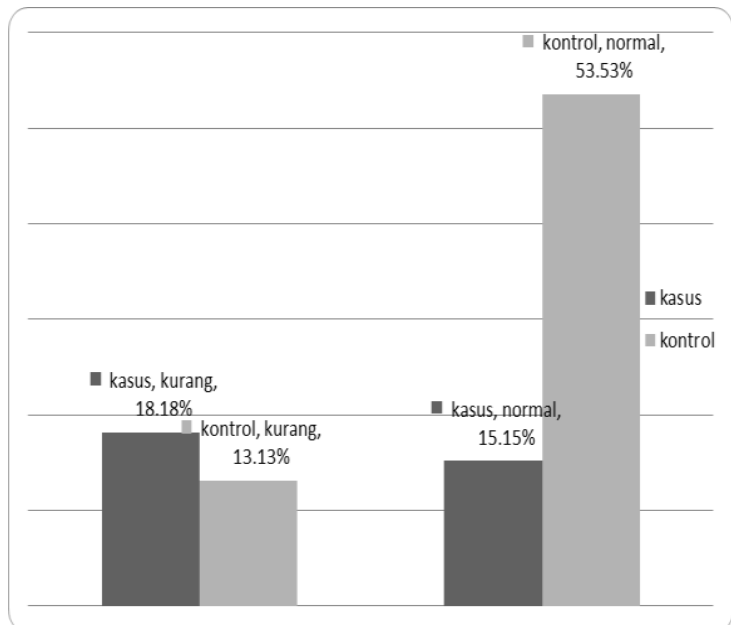

Diagram 7 Distribusi frekuensi responden berdasarkan kenaikan berat badan (BB) ibu selama hamil trimester III di Puskesmas Paleran Kecamatan Umbulsari Kabupaten Jember Berdasarkan diagram 7 diatas, menunjukkan sebagian besar responden memiliki kenaikan berat badan pada Trimester III yang dalam kategori normal yaitu sebanyak 53 responden $(53,53 \%)$.

Hubungan kenaikan berat badan ibu hamil trimester III dengan Kejadian BBLR di Puskesmas Paleran Kecamatan Umbulsari Kabupaten Jember.

Tabulasi silang hubungan antara skor kenaikan berat badan ibu hamil trimester III dengan kejadian BBLR disajikan pada 
tabel 2.1 berikut.

Tabel 1 Tabel kontingensi $2 \times 2$ antara Kriteria Skor kenaikan berat badan ibu hamil trimester III dengan kejadian BBLR.

\begin{tabular}{|c|c|c|c|c|c|c|}
\hline \multirow{3}{*}{$\begin{array}{l}\text { Kriteria } \\
\text { skor BMI }\end{array}$} & \multicolumn{4}{|c|}{ Kejadian BBLR } & \multirow{2}{*}{\multicolumn{2}{|c|}{ Total }} \\
\hline & \multicolumn{2}{|c|}{ BBLR } & \multicolumn{2}{|c|}{$\begin{array}{l}\text { Tidak } \\
\text { BBLR } \\
\end{array}$} & & \\
\hline & $\begin{array}{l}\text { Fre } \\
\mathrm{k}\end{array}$ & $\%$ & $\begin{array}{l}\text { Fr } \\
\text { ek }\end{array}$ & $\%$ & $\begin{array}{l}\text { Fre } \\
\mathrm{k}\end{array}$ & $\%$ \\
\hline Kurang & 18 & $\begin{array}{l}18 \\
, 2\end{array}$ & 13 & 13,1 & 31 & 31,3 \\
\hline normal & 15 & $\begin{array}{l}15 \\
, 2\end{array}$ & 53 & 53,4 & 68 & 68,7 \\
\hline Total & 33 & $\begin{array}{l}33 \\
, 3\end{array}$ & 66 & 66,7 & 99 & 100 \\
\hline \multicolumn{7}{|l|}{$\begin{array}{l}X^{2=}=10,855 \\
O R=4.892\end{array}$} \\
\hline \multicolumn{7}{|c|}{$\begin{array}{l}X^{2} \text { Tabel }=1,985 \\
\text { Kesalahan5\% } \\
P=001\end{array}$} \\
\hline
\end{tabular}

antara kriteria skor kenaikan berat badan ibu hamil dengan kejadian BBLR (Tabel 2.1), diperoleh hasil sebanyak 31 responden $(31,3 \%)$ yang memiliki kenaikan berat badan dalam katagori kurang dan dari jumlah tersebut terdapat 18 responden $(18,2 \%)$ yang terjadi BBLR dan sisanya sebanyak 13 responden (13,1\%) tidak terjadi BBLR. Responden yang memiliki kenaikan berat badan dalam kategori normal sebesar $68,7 \%$ (68 responden), dari jumlah tersebut terdapat 15 responden $(15,2 \%)$ dengan kejadian BBLR dan sisanya sebanyak 53 responden $(53,4 \%)$ tidak terjadi BBLR.

Hubungan antara kenaikan berat badan ibu hamil trimester III dengan kejadian BBLR dihitung dengan menggunakan SPSS dengan memakai rumus Chi-Square. Didapatkan hasil $X^{2}$ hitung sebesar 10,855 sedangkan nilai tabel $=1,985$ dan $p=001$ dengan menggunakan taraf kesalahan signifikan $5 \%=0,05$. Maka 10,855 > 1,985. Besar resiko terjadinya BBLR pada ibu yang kenaikan berat badannya tidak normal adalah 4,892 kali dari pada berat badan ibu yang kenaikannya normal. Dari perhitungan diatas maka diperoleh hasil $\mathrm{H}_{0}$ ditolak dan $\mathrm{H}_{1}$ diterima. Hal ini berarti bahwa terdapat hubungan yang bermakna antara kenaikan berat badan ibu hamil trimester III dengan kejadian BBLR.

\section{Pembahasan \\ Kenaikan Berat Badan Ibu Hamil Trimester III di Puskesmas Paleran Kecamatan Umbulsari Kabupaten Jember.}

Hasil penelitian terhadap bayi baru lahir dilayanan kesehatan puskesmas Paleran ditemukan kasus BBLR masih tinggi yaitu sebanyak 33 responden (33,3\%), faktor penyebabnya sebagian besar karena kenaikan berat badan ibu hamil trimester III yang tidak normal. Disini ditemukan 18 responden $(18,18 \%)$ yang status gizi ibu dalam kategori kurang. Peningkatan berat badan selama hamil dapat menentukan kelangsungan hasil akhir kehamilan. Bila ibu hamil kurus atau gemuk sebelum hamil akan menimbulkan risiko pada janin terutama apabila peningkatan atau penurunan sangat menonjol. Bila sangat kurus maka akan melahirkan bayi BBLR (Salmah, 2006).

Berdasarkan usia ibu hamil sebagian besar berumur antara 20-35 tahun yaitu sebanyak 50 responden $(50,50 \%)$. Data ini menunjang bahwa kondisi kesehatan atau gizi ibu hamil di wilayah kerja Puskesmas Paleran baik. Menurut (Arisman, 2010) umur atau usia sangat mempengaruhi status gizi ibu hamil pada waktu pembuahan dan selama hamil sebab umur diperlukan untuk menentukan besaran kalori serta zat gizi yang akan diberikan. Semakin muda umur seseorang wanita yang hamil, maka lebih banyak energi yang diperlukan dan tingkat risiko morbiditas (terkena penyakit) dan mortalitas (tingkat kematian) pada ibu dan janin akan meningkat daripada kehamilan pada usia reproduksi yang sehat. Usia yang disinyalir rawan untuk hamil adalah usia yang kurang atau lebih dari rentang usia reproduksi sehat tersebut. Dari hasil penelitian didapatkan sebagian besar berpendidikan SD yaitu sebanyak 26 responden $(26,20 \%)$. Tetapi hal ini tidak mempengaruhi kondisi kesehatan atau gizi ibu hamil di wilayah kerja Puskesmas Paleran sebab sebagian besar kondisi kesehatan ibu hamil di Puskesmas Paleran baik. Menurut (Latipun, 2011) bahwa tingkat pendidikan mempengaruhi cara pandang seseorang terhadap diri dan lingkungannya, karena itu akan berbeda sikap klien yang berpendidikan tinggi dibandingkan yang berpendidikan rendah. Tetapi menurut (Notoadmodjo, 2003) dari pengalaman dan penelitian terbukti bahwa perilaku yang didasari oleh pengetahuan akan lebih langgeng daripada perilaku yang tidak didasari oleh pengetahuan merupakan hasil "tahu dan ini terjadi setelah orang melakukan pengindraan, pendengaran, penciuman, rasa, dan raba. Pengetahuan/kognitif merupakan domain yang sangat penting untuk terbentuknya tindakan seseorang (overt behaviour).

Kejadian BBLR di Puskesmas Paleran Kecamatan Umbulsari Kabupaten Jember. 
Dari hasil penelitian terhadap bayi baru lahir di Puskesmas Paleran kasus BBLR masih tinggi yaitu sebanyak 33 responden $(33,3 \%)$. Ini menunjukkan bahwa sebagian besar kondisi kesehatan atau gizi ibu hamil di wilayah kerja Puskesmas Paleran masih dalam kategori kurang. Menurut (Arisman, 2010) pada tahap trimester III terjadi pertumbuhan janin dan plasenta serta pertambahan cairan amnion berlangsung sangat cepat sehinggga perlu diperhatikan kebutuhan gizi ibu selama periode ini. Pada ibu yang menderita malnutrisi sepanjang minggu terakhir kehamilannya atau pada trimester III akan melahirkan bayi dengan berat badan lahir rendah (BBLR) yaitu berat badan bayi < 2500 gram. Berat badan ibu hamil harus bertambah sesuai umur kehamilan, kenaikan berat badan yang normal akan menghasilkan anak yang normal. Seorang ibu yang sedang hamil mengalami kenaikan berat badan sebanyak 10-12 kg. Pada trimester ketiga kenaikan berat badan mencapai kira-kira $6 \mathrm{~kg}$ yaitu diperkirakan 90\% kenaikan itu merupakan kenaikan komponen janin, seperti pertumbuhan janin, plasenta, dan bertambahnya cairan amnion (Huliana 2006).

Menurut (Arisman, 2010) pada ibu yang menderita malnutrisi sepanjang minggu terakhir kehamilannya atau pada trimester III akan melahirkan bayi dengan berat badan lahir rendah (BBLR) yaitu berat badan bayi $<2500$ gram, karena jaringan lemak banyak tertimbun selama trimester III .

Hubungan Kenaikan Berat Badan Ibu Hamil Trimester III dengan BBLR di Puskesmas Paleran Kecamatan Umbulsari Kabupaten Jember.

Hasil perhitungan dengan SPSS menggunakan rumus Chi-Square sebesar 10,855 sedangkan X2 tabel sebesar 1.982, dan $p=001$ dengan menggunakan taraf kesalahan signifikan $5 \%=0,05$. Hal tersebut menunjukkan 10,855 > 1,982. Besar resiko terjadinya BBLR pada ibu hamil yang kenaikan berat badannya tidak normal adalah 4,892 kali daripada kenaikan berat badan ibu hamil trimester III yang normal. Sehingga dapat disimpulkan "Ada hubungan antara kenaikan berat badan ibu selama hamil Trimester III dengan berat badan bayi baru lahir rendah (BBLR)", diterima dan memiliki hubungan yang signifikan. Ternyata ibu hamil yang mengalami kenaikan/penurunan berat badan selama trimester III mempengaruhi kesempurnaan perkembangan janin selama dalam kandungannya, tetapi belum tentu semua ibu hamil yang mengalami kenaikan/penurunan berat badan selama trimester III selalu melahirkan BBLR, karena banyak faktor yang mempengaruhi kelahiran BBLR. Sebab menurut (Arisman, 2010) berat lahir lebih berkolerasi positif dengan pertambahan berat total selama hamil. Dan selain faktor pertambahan berat badan masih banyak faktor-faktor lain yang mempengaruhi berat badan bayi baru lahir. Berat badan lahir (BBL) merupakan indeks yang terburuk untuk menentukan masa gestasi neonatus. Hal ini disebabkan BBL sangat dipengaruhi oleh banyak faktor. BBL kurang atau sama dengan 2500 gram tidak dapat dipandang sebagai unit yang homogen. Bayi BBLR dapat merupakan bayi prematur murni atau dismatur. Jadi lama masa gestasi untuk BBLR sangat bervariasi.

Pada bayi dengan premature murni masa gestasinya kurang dari 37 minggu dan berat badannya sesuai dengan berat badan untuk masa gestasi itu atau biasa disebut neonatus kurang bulan sesuai untuk masa kehamilan. Penyebabnya berasal dari berbagai faktor ibu (penyakit, usia, keadaan sosial-ekonomi), faktor janin (hidramnion, kehamilan ganda umumnya akan mengakibatkan lahirnya bayi BBLR) (Wahidiyat, 2007). Sedangkan untuk dismaturitas bayi lahir dengan berat badan kurang dari berat badan seharusnya untuk masa gestasi itu. Berarti bayi mengalami retardasi pertumbuhan intrauterine dan merupakan bayi yang kecil untuk masa kehamilannya. Kemudian dari faktor penyakit misalnya pada penderita penyakita anemia adalah dapat didefinisikan sebagai kondisi dengan kadar $\mathrm{Hb}$ berada di bawah normal.

Anemia defisiensi besi merupakan salah satu gangguan yang paling sering terjadi selama kehamilan. Ibu hamil umumnya mengalami depresi besi sehingga hanya memberi sedikit besi kepada janin yang dibutuhkan untuk metabolisme besi yang normal. Selanjutnya mereka akan menjadi anemia pada saat kadar hemoglobin ibu turun sampai di bawah $11 \mathrm{gr} / \mathrm{dl}$ selama trimester III. Kekurangan zat besi dapat menimbulkan gangguan atau hambatan pada pertumbuhan janin baik sel tubuh maupun sel otak. Anemia gizi dapat mengakibatkan kematian janin didalam kandungan, abortus, cacat bawaan, BBLR, anemia pada bayi yang dilahirkan, hal ini menyebabkan morbiditas dan mortalitas ibu dan kematian perinatal secara bermakna lebih tinggi. Pada ibu hamil yang menderita anemia berat dapat meningkatkan resiko morbiditas maupun mortalitas ibu dan bayi, kemungkinan melahirkan bayi BBLR dan premature. Dari hasil pembahasan diatas maka dapat disimpulkan bahwa "Ada hubungan antara kenaikan berat badan ibu selama hamil Trimester III dengan BBLR" 


\section{Kesimpulan Dan Saran}

Kesimpulan

Dari hasil penelitian ini dapat diambil kesimpulan sebagaimana berikut:

a. Sebagian besar kenaikan berat badan ibu hamil pada trimester III dalam kategori gizi kurang yaitu sebanyak 18 responden (18,18\%).

b. Angka kejadian BBLR masih tinggi di Puskesmas Paleran yaitu sebanyak 33 responden $(33,3 \%)$.

c. Ada hubungan yang signifikan antara kenaikan berat badan ibu selama hamil trimester III dengan berat badan bayi baru lahir rendah (BBLR). Sehingga dapat disimpulkan bahwa status kenaikan berat badan ibu selama hamil trimester III yang baik akan melahirkan bayi yang cukup berat badannya.

Saran

Bagi Program Pemerintah

1. Mengurangi angka prevalensi gizi kurang pada ibu hamil agar tidak terjadi kelahiran bayi BBLR.

2. Memberikan bantuan makanan tambahan (PMT) seperti: susu telor, buah-buahan bagi ibu hamil yang mengalami gizi kurang.

Bagi Masyarakat/lbu Hamil

1. Menjaga kesehatan kehamilan dan berusaha menaikan berat badan agar tidak mengalami gizi kurang, untuk menghindari resiko melahirkan bayi BBLR.

2. Mengkonsumsi makanan yang bergizi saat hamil, serta mendapat tambahan protein, mineral, vitamin, dan energi agar ibu dan janin dalam keadaan sehat.

\section{Daftar Pustaka}

Arisman, 2010. Gizi dalam Daur Kehidupan. Jakarta: EGC

Budiman, Charles. 2011. Tesis: Korelasi Antara Berat Badan Ibu Hamil dengan Berat Lahir Bayi. Semarang: Universitas Diponegoro.

http://eprints.undip.ac.id/32931/1/Charles. pdf

Cunningham, G. F. 2014. Obstetri Williams. Jakarta: EGC

Fajrina, Adiba. 2011. Hubungan Pertambahan Berat Badan Ibu Hamil dan Karakteristik Ibu dengan Berat Lahir di Cibinong Tahun 2004.2011. Journal Ners and Midwifery Indonesia.

http://almaata.ac.id/ejournal1532/index.ph $\mathrm{p} / \mathrm{JNKl} /$ article/view/219/pdf1
Francin, E. dkk. 2014. Gizi dalam Kesehatan Reproduksi. Jakarta: EGC

ICSU, ISSC. 2015. Review of the Suistanable Development Goals: The Science Perspective. Paris

Kemenkes RI, 2014. Pedoman Gizi Seimbang. Jakarta: Kemenkes RI

Latipun, 2011. Psikologi Konseling. Malang: UMM Press

Manuaba, I.2010. IImu Kebidanan, Penyakit Kandungan dan KB untuk Pendidikan Bidan. Jakarta: EGC

Notoatmodjo, S. 2003. Pendidikan dan Prilaku Kesehatan. Jakarta: PT Rieka Cipta

Prawirohardjo, S. 2016. IImu Kebidanan. Jakarta: Yayasan Bina Pustaka Sarwono Prawirohardjo.

Puspitasari, Cinde. 2011. Hubungan Antara Kenaikan Berat Badan Selama Kehamilan dengan Berat Bayi Baru Lahir di Wilayah Kerja Puskesmas Rawalo Kabupaten Banyumas Tahun 2009-2010. Jurnal IImiah Kebidanan, Vol. 2 No. 1 Edisi Juni 2011.

http://www.ojs.akbidylpp.ac.id/index.php/P rada/article/view/51/49

Supariasa, I Dewa Nyoman.dkk. 2016. Penilaian Status Gizi Edisi 2. Jakarta: Buku Kedokteran EGC 